\title{
Detection of Laem-Singh virus in cultured Penaeus monodon shrimp from several sites in the Indo-Pacific region
}

\author{
Nusra Sittidilokratna ${ }^{1,2,6}$, Sirintip Dangtip ${ }^{2}$, Kallaya Sritunyalucksana ${ }^{1,2}$, \\ Ravi Babu ${ }^{3}$, Balakrishnan Pradeep ${ }^{4}$, C. V. Mohan ${ }^{5}$, Nicholas Gudkovs ${ }^{6}$, Peter J. Walker ${ }^{6, *}$ \\ ${ }^{1}$ National Center for Genetic Engineering and Biotechnology (BIOTEC), National Science and Technology Development \\ Agency, Phathumthani 12120, Thailand \\ ${ }^{2}$ Center of Excellence for Shrimp Molecular Biology and Biotechnology, Faculty of Science, Mahidol University, Rama VI Road, \\ Phyathai, Bangkok 10400, Thailand \\ ${ }^{3}$ National Centre for Sustainable Aquaculture, 69-17-8, SBI Officers Colony, Rajendra Nagar, Kakinada 533003, \\ Andhra Pradesh, India \\ ${ }^{4}$ Department of Fishery Microbiology, Karnataka Veterinary, Animal and Fisheries Sciences University, College of Fisheries, \\ Mangalore 575002, India \\ ${ }^{5}$ Network of Aquaculture Centers Asia-Pacific (NACA), Suraswadi Building, Kasetsart University Campus, Ladyao, Jatujak, \\ Bangkok 10900, Thailand \\ ${ }^{6}$ CSIRO Livestock Industries, Australian Animal Health Laboratory (AAHL), 5 Port Arlington Road, Geelong, Victoria 3220, \\ Australia
}

\begin{abstract}
Laem-Singh virus (LSNV) is a positive-sense single-stranded RNA (ssRNA) virus that was recently identified in Penaeus monodon shrimp in Thailand displaying signs of slow growth syndrome. A total of 326 shrimp collected between 1998 and 2007 from countries in the Indo-Pacific region were tested by RT-PCR for evidence of LSNV infection. The samples comprised batches of whole postlarvae, and lymphoid organ, gill, muscle or pleopod tissue of juvenile, subadult and adult shrimp. LSNV was not detected in 96 P. monodon, P. japonicus or P. merguiensis from Australia or 16 P. monodon from Fiji, Philippines, Sri Lanka and Mozambique. There was no evidence of LSNV infection in 73 healthy juvenile $P$. vannamei collected during 2006 from ponds at 9 locations in Thailand. However, LNSV was detected in each of 6 healthy $P$. monodon tested from Malaysia and Indonesia, 2 of 6 healthy P. monodon tested from Vietnam and 39 of 40 P. monodon collected from slow-growth ponds in Thailand. A survey of 81 P. monodon collected in 2007 from Andhra Pradesh, India, indicated $56.8 \%$ prevalence of LSNV infection but no clear association with disease or slow growth. Phylogenetic analysis of PCR amplicons obtained from samples from India, Vietnam, Malaysia and Thailand indicated that nucleotide sequence variation was very low (>98\% identity) and there was no clustering of viruses according to site of isolation or the health status of the shrimp. The data suggests that LSNV exists as a single genetic lineage and occurs commonly in healthy $P$. monodon in parts of Asia.
\end{abstract}

KEY WORDS: Laem Singh virus · Shrimp · Geographic distribution

\section{INTRODUCTION}

Laem-Singh virus (LSNV) was first identified in black tiger shrimp Penaeus monodon collected from ponds in Laem Singh Province in Thailand in 2003 (Sritunyalucksana et al. 2006). It is a positive-sense single-stranded RNA virus (ssRNA, 25 to $30 \mathrm{~nm}$ ) that appears to be most closely related to the insect-transmitted plant viruses in the family Leuteoviridae. The shrimp in which LSNV was first detected displayed signs of monodon slow growth syndrome (MSGS), a condition that has been widespread in cultured $P$. 
monodon in Thailand since 2001 and is considered to be of infectious aetiology (Chayaburakul et al. 2004). MSGS has caused serious economic loss in Thailand and a similar condition has subsequently been reported in P. monodon in East Africa (Anantasomboon et al. 2006). Several other viruses, including a yellowhead-complex virus and a small icosahedral cytoplasmic virus, have been identified in MSGS shrimp. LSNV has also been detected in healthy shrimp and there is apparently no correlation between LSNV infection and slow growth (Chayaburakul et al. 2004, Sritunyalucksana et al. 2006, Anantasomboon et al. 2006). However, persistent infection in the absence of disease is a characteristic of many shrimp viruses, for which pathology may be induced by environmental factors (Walker \& Mohan in press), and the possible involvement of LSNV in MSGS or other diseases of shrimp remains unclear.

\section{MATERIALS AND METHODS}

In the present study, 326 samples of Penaeus monodon, P. vannamei, P. mergiuensis and P. japonicus collected between 1998 and 2007 from 10 countries in the Indo-Pacific region were tested by RT-PCR and/or RTnested PCR for evidence of LSNV infection. The samples comprised batches of whole postlarvae, and lymphoid organ, gill, muscle or pleopod tissue of juvenile, subadult and adult shrimp. Tissues were collected in $90 \%$ aqueous ethanol or RNAlater (Ambion), transported at room temperature and stored at $-20^{\circ} \mathrm{C}$. Total RNA was extracted using TRIzol Reagent (Invitrogen) as described by the manufacturer, precipitated under ethanol, resuspended in RNase-free water and stored at $-80^{\circ} \mathrm{C}$ until required.

Initially, screening for the presence of LSNV was conducted by RT-PCR using a modification of the method described previously (Sritunyalucksana et al. 2006). For cDNA synthesis, a TaqMan ${ }^{\circledR}$ Gold RT-PCR Kit (Applied Biosystems) was used in a $10 \mu \mathrm{l}$ volume containing 50 to $100 \mathrm{ng}$ total RNA, TaqMan RT Buffer, $5.5 \mathrm{mM} \mathrm{MgCl}_{2}, 500 \mu \mathrm{M}$ of each dNTP, $2.5 \mu \mathrm{M}$ random hexamer primers, $4 \mathrm{U}$ of RNase inhibitor and $12.5 \mathrm{U}$ of MultiScribe reverse transcriptase. The reverse transcription reaction cycle was $25^{\circ} \mathrm{C}$ for $10 \mathrm{~min}, 48^{\circ} \mathrm{C}$ for $30 \mathrm{~min}$ and $95^{\circ} \mathrm{C}$ for $5 \mathrm{~min}$. PCR was conducted in a $25 \mu \mathrm{l}$ volume containing $1 \mu \mathrm{l}$ of first-strand cDNA, $2.5 \mathrm{U}$ of Platinum ${ }^{\circledR}$ Taq DNA Polymerase (Invitrogen), Platinum PCR Buffer, $200 \mu \mathrm{M}$ of each dNTP and $0.4 \mu \mathrm{M}$ of each primer BLF (5'-CGT TGC CTT CTC CCG AGT GGT-3') and LR1 (5'-AAT CTC ACC ATG AAG CTC CTC AC-3'). The amplification profile employed an initial activation step of $94^{\circ} \mathrm{C}$ for $2 \mathrm{~min}$, followed by 35 cycles of $94^{\circ} \mathrm{C}$ for $30 \mathrm{~s}, 60^{\circ} \mathrm{C}$ for $30 \mathrm{~s}$ and $72^{\circ} \mathrm{C}$ for $30 \mathrm{~s}$, and a final extension at $72^{\circ} \mathrm{C}$ for 7 min. As there was some concern that the RT-PCR may not be sufficiently sensitive to detect LSNV in some healthy shrimp, the procedure was subsequently modified to include a nested reaction. The nested PCR used $1 \mu \mathrm{l}$ of the primary PCR and the same reaction components, except for the substitution of nested primers LF2 (5'-AGA TCA TGC TGC ATA TGC TTG C-3') and LR2 (5'-GTG TAG ATT GGT TGC ATG GCG-3') and a reduced annealing temperature $\left(58^{\circ} \mathrm{C}\right)$. Amplified DNA products ( 357 and $205 \mathrm{bp}$ ) were resolved in a $2 \%$ agaroseTAE gel containing $0.5 \mu \mathrm{g} \mathrm{ml}^{-1}$ ethidium bromide alongside a $1 \mathrm{~kb}$ PLUS DNA ladder (Invitrogen) and visualized using a UV transilluminator.

\section{RESULTS}

Screening by RT-PCR and RT-nested PCR detected no evidence of LSNV infection in lymphoid organ or gill tissue of 96 healthy juvenile or adult Penaeus monodon, P. merguiensis or P. japonicus from northern and eastern Australia between 1998 and 2006 (Table 1). LSNV was also not detected by RT-PCR in healthy $P$. monodon juveniles from Fiji, healthy broodstock from Mozambique or batches of healthy $P$. monodon postlarvae from India, Sri Lanka or the Philippines. LSNV was detected by RT-PCR in healthy juvenile P. monodon from Thailand, Malaysia and Indonesia, but was not detected in 3 juvenile $P$. monodon from yellow head disease outbreak ponds in Thailand. The RT-nested PCR was also used to retest $P$. monodon samples from the Asian region that had previously been screened by the original RT-PCR. The increased analytical sensitivity of the test allowed detection of LSNV in 3 additional samples, 2 from Vietnam and 1 from Malaysia.

During April and May 2006, 73 healthy juvenile Penaeus vannamei were collected from ponds at 9 locations in central and southern Thailand, and 40 juvenile $P$. monodon were collected from slow-growth ponds in Samroiyod (15 shrimp) and Pakphanang (25 shrimp) in Southern Thailand (Table 2). RT-PCR indicated no evidence of LSNV infection in lymphoid organ, gill or pleopod tissue of $P$. vannamei. However, LSNV was detected in the lymphoid organs of 39 of 40 P. monodon ( $97.5 \%$ prevalence) collected from slow-growth ponds.

In April 2007, juvenile to subadult Penaeus monodon were collected from 81 ponds in the Krishna District and the East and West Godavari Districts of Andhra Pradesh, India (Table 3). Each sample comprised pooled gill tissue of 6 to 8 shrimp from each pond. Samples were collected between 15 and $135 \mathrm{~d}$ after the seeding of ponds (mean $=61.6 \mathrm{~d}$ ) and were either observed to be healthy (63 samples) or were 
Table 1. RT-PCR testing for Laem-Singh virus in shrimp tissue (Penaeus monodon, P. merguiensis and P. japonicus) samples collected from farmed shrimp and broodstock sourced from the wild at various locations in the Indo-Pacific region from 1998 to 2006. LO: lymphoid organ; nt: not tested

\begin{tabular}{|c|c|c|c|c|c|c|c|}
\hline \multirow[t]{2}{*}{ Country } & \multirow[t]{2}{*}{ Species } & \multirow[t]{2}{*}{ Year } & \multirow[t]{2}{*}{ Stage } & \multirow[t]{2}{*}{ Tissue } & \multirow{2}{*}{$\begin{array}{c}\text { No. } \\
\text { tested }\end{array}$} & \multicolumn{2}{|c|}{ LSNV RT-PCR } \\
\hline & & & & & & Primary & Nested \\
\hline \multirow[t]{8}{*}{ Australia } & P. monodon & 1998 & Broodstock & LO & 10 & 0 & 0 \\
\hline & P. monodon & 2000 & Broodstock & LO & 22 & 0 & 0 \\
\hline & P. monodon & 2002 & Broodstock & LO & 24 & 0 & 0 \\
\hline & P. monodon & 2003 & Broodstock & $\mathrm{LO}$ & 5 & 0 & nt \\
\hline & P. monodon & 2004 & Broodstock & Gill & 5 & 0 & nt \\
\hline & P. monodon & 2006 & Broodstock & Gill & 20 & 0 & 0 \\
\hline & P. merguiensis & 2003 & Juvenile & LO & 5 & 0 & nt \\
\hline & P. japonicus & 2002 & Broodstock & $\mathrm{LO}$ & 5 & 0 & nt \\
\hline Fiji & P. monodon & 2003 & Subadult & Gill & 8 & 0 & nt \\
\hline Thailand & P. monodon & 2000 & Juvenile & Pleopod & $4^{\mathrm{a}}$ & 1 & 4 \\
\hline Vietnam & P. monodon & 2002 & Postlarvae & Whole & 6 & 0 & 2 \\
\hline Indonesia & P. monodon & 2004 & Subadult & Muscle & 4 & 4 & nt \\
\hline Malaysia & P. monodon & 2003 & Subadult & Pleopod & 2 & 1 & 2 \\
\hline Philippines & P. monodon & 2003 & Postlarvae & Whole & 2 & 0 & 0 \\
\hline India & P. monodon & 2002 & Postlarvae & Whole & 2 & 0 & 0 \\
\hline Sri Lanka & P. monodon & 2002 & Juvenile & Gill & 3 & 0 & 0 \\
\hline Mozambique & P. monodon & 2004 & Broodstock & Gill & 5 & 0 & 0 \\
\hline
\end{tabular}

Table 2. Detection of Laem-Singh virus (LSNV) by RT-PCR in shrimp (Penaeus monodon and P. vannamei) samples collected from ponds in central and southern Thailand in April and May 2006. Slow growth: status given according to the case definition described by Sritunyalucksana et al. (2006)

\begin{tabular}{|c|c|c|c|c|c|}
\hline Species & Location & Life stage & Health status & No. samples & LSNV RT-PCR \\
\hline \multirow[t]{2}{*}{ P. monodon } & Samroiyod & Juvenile & Slow growth & 15 & 14 \\
\hline & Pakphanang & Juvenile & Slow growth & 25 & 25 \\
\hline \multirow[t]{9}{*}{ P. vannamei } & Ratchaburi & Juvenile & Healthy & 4 & 0 \\
\hline & Phetchaburi & Juvenile & Healthy & 31 & 0 \\
\hline & Samut Songkhram & Juvenile & Healthy & 12 & 0 \\
\hline & Chachoeungsao & Juvenile & Healthy & 7 & 0 \\
\hline & Trat & Juvenile & Healthy & 3 & 0 \\
\hline & Rayong & Juvenile & Healthy & 4 & 0 \\
\hline & Chantaburi & Juvenile & Healthy & 3 & 0 \\
\hline & Prachuap khiri khan & Juvenile & Healthy & 3 & 0 \\
\hline & Chumporn & Juvenile & Healthy & 6 & 0 \\
\hline
\end{tabular}

from ponds in which the shrimp displayed various signs of disease including slow growth (2 ponds). LSNV was detected in 39 samples using the original RT-PCR and in 46 samples using the improved RTnested PCR (56.8\% prevalence). Evidence of LSNV infection was detected in shrimp from 35 of the 63 healthy ponds (55.6\% prevalence) and 11 of the 18 diseased ponds (61.1\% prevalence), including 1 of the 2 slow-growth ponds. LSNV was detected in samples collected from ponds with the shortest (15 d) and longest $(135 \mathrm{~d}$ ) duration of grow-out (mean $=47.4 \mathrm{~d}$ ). There was no obvious clustering of positive samples according to the site of collection.

Amplicons generated by RT-PCR from a set of 25 viruses detected in Penaeus monodon from India,
Vietnam, Malaysia and Thailand were gel-purified using QIAquick columns (QIAGEN) and sequenced directly in both directions using primers BLF and LR1. Sequencing was performed at the Australian Genome Research Facility, Brisbane, Australia, and chromatograms were edited using SeqEd 1.0.3 (ABI). The sequences have been deposited in GenBank under accession nos. FJ811829 to FJ811836. A ClustalX multiple alignment of the 199 nucleotide (nt) sequence of these viruses and the Thai LSNV reference sequence (Genbank DQ127905) were used to construct a phylogenetic tree using the neighbour-joining distance method (Saitou \& Nei 1987). The nucleotide sequence variation amongst this set of viruses in this small amplicon was very low (>98\% identity) (Fig. 1). For a set of 
Table 3. Detection of Laem-Singh virus (LSNV) by RT-PCR in Penaeus monodon samples collected from 81 ponds in the Krishna and Godavari Districts of Andhra Pradesh, India, in August 2007. +: LSNV-positive. Blanks: LSNV-negative. Diseased: status as defined by Padiyar (2009). Slow growth: see definition in Table 2

\begin{tabular}{|c|c|c|c|c|c|c|c|c|c|}
\hline \multirow[t]{2}{*}{ Location } & \multirow{2}{*}{$\begin{array}{l}\text { Day of } \\
\text { crop }\end{array}$} & \multirow{2}{*}{ Health status } & \multicolumn{2}{|c|}{ LSNV RT-PCR } & \multirow[t]{2}{*}{ Location } & \multirow{2}{*}{$\begin{array}{l}\text { Day of } \\
\text { crop }\end{array}$} & \multirow[t]{2}{*}{ Health status } & \multicolumn{2}{|c|}{ LSNV RT-PCR } \\
\hline & & & Primary & Nested & & & & Primary & Nested \\
\hline Statimpeta & 15 & Diseased & + & + & Mallavarama & 60 & Healthy & + & + \\
\hline Kommuchikkala & 20 & Healthy & + & + & Modlachervu & 60 & Healthy & & \\
\hline Mandapakala & 20 & Healthy & & + & Mulapolam & 60 & Diseased & & \\
\hline Nelapogula & 20 & Healthy & & & Nelamuru & 60 & Healthy & & + \\
\hline Мура & 27 & Healthy & & + & Pendurru & 60 & Healthy & + & + \\
\hline Kalagampudi & 30 & Healthy & & & Polekuri & 60 & Healthy & & \\
\hline Nali & 30 & Healthy & & & Thillapudipalem & 60 & Healthy & + & + \\
\hline Gadimora & 39 & Healthy & & & Aratlakatta & 63 & Diseased & + & + \\
\hline Adavipalem & 40 & Healthy & + & + & Kotanavarasapuram & 63 & Healthy & & \\
\hline Kotablock & 40 & Healthy & + & + & Gajuladeevi & 65 & Healthy & & \\
\hline Likilhapudi & 40 & Healthy & & & Kesudaspalem & 65 & Healthy & + & + \\
\hline Mogalamurru & 40 & Healthy & & & Penurrapara & 65 & Healthy & + & + \\
\hline Potumedha & 40 & Healthy & + & + & Panjavemavarum & 66 & Healthy & + & + \\
\hline Rudarveram & 40 & Healthy & + & + & Dharbakerri & 67 & Healthy & + & + \\
\hline Edurulanka & 45 & Healthy & & & Agarllupalam & 70 & Healthy & & \\
\hline Chintalamori & 45 & Diseased & & + & Chinnamannidipalli & 70 & Healthy & + & + \\
\hline Konithivada & 45 & Healthy & + & + & Devarapalli & 70 & Healthy & + & + \\
\hline Mangalaguntapalem & 45 & Diseased & + & + & Kamanamolu & 70 & Healthy & & \\
\hline Venkatapurram & 45 & Healthy & & & Madugupolavaram & 70 & Slow growth & & \\
\hline Antarvedi & 48 & Healthy & & & Modlalanka & 70 & Healthy & & \\
\hline Gondhi & 50 & Diseased & & + & Podlapalli & 70 & Healthy & + & + \\
\hline Kamannamodi & 50 & Healthy & + & + & Ratulanka & 70 & Healthy & & \\
\hline Khatimanda & 50 & Diseased & + & + & Vendra & 70 & Diseased & + & + \\
\hline Mallavaram & 50 & Healthy & & + & Korukallu & 75 & Healthy & + & + \\
\hline Modlagondhi & 50 & Healthy & & & Agassamijasugusta & 80 & Healthy & + & + \\
\hline Pennamavaridibba & 50 & Healthy & & & Malkipuram & 80 & Healthy & + & + \\
\hline Sitarampuram & 50 & Healthy & & & Sivadevnichikkala & 80 & Healthy & + & + \\
\hline Shankaguptam & 50 & Healthy & + & + & Konithivada & 87 & Slow growth & + & + \\
\hline Ullipamel & 54 & Healthy & & & SSAC & 87 & Healthy & + & + \\
\hline Kodurupadu & 55 & Healthy & & & Chamakurupalem & 90 & Healthy & & + \\
\hline Velilela & 57 & Healthy & + & + & Chandaparru & 90 & Diseased & + & + \\
\hline Bavadevarapalli & 60 & Healthy & & & Chinapootlapudi & 90 & Diseased & & \\
\hline Bhaskarraokta & 60 & Diseased & & & Srungavrusham & 90 & Healthy & + & + \\
\hline Chinapandraka & 60 & Diseased & & & Yendapalli & 90 & Healthy & + & + \\
\hline Chorampudi & 60 & Healthy & & & Alamura & 100 & Diseased & + & + \\
\hline Dinti & 60 & Healthy & & & Rayakudura & 107 & Healthy & & \\
\hline Durgapuram & 60 & Diseased & & & Sangameshwaram & 111 & Diseased & & \\
\hline Godilanka & 60 & Healthy & & & Muratapalem & 120 & Healthy & + & + \\
\hline Kondepudi & 60 & Healthy & + & + & Oduru & 120 & Diseased & + & + \\
\hline Kopparu & 60 & Healthy & & & Muramalla & 135 & Healthy & + & + \\
\hline Laxmaneswaram & 60 & Healthy & + & + & & & & & \\
\hline
\end{tabular}

8 viruses from Thailand, Malaysia and India, the sequence was identical to the Thai reference strain. Amongst the other viruses, there was no clustering according to site of isolation, either internationally or within the collection site in Andhra Pradesh, and there was no evidence of clustering according to whether the source shrimp were healthy or diseased.

\section{DISCUSSION}

The results of the present study indicate that LSNV occurs commonly in Penaeus monodon at some loca- tions in South and Southeast Asia. This was evident from the high prevalence of LSNV infection in $P$. monodon sampled from Thailand and India and the ease with which the virus was detected in the small numbers of shrimp tested from Malaysia, Indonesia and Vietnam. In contrast, there was no evidence of LSNV infection in the significant number of $P$. monodon tested from the east coast of Australia between 1998 and 2006, suggesting either absence from that population or a relatively low prevalence of infection. Although there was no evidence of infection in other penaeid shrimp species, the numbers of Australian $P$. japonicus and P. mergiuensis tested were small and 


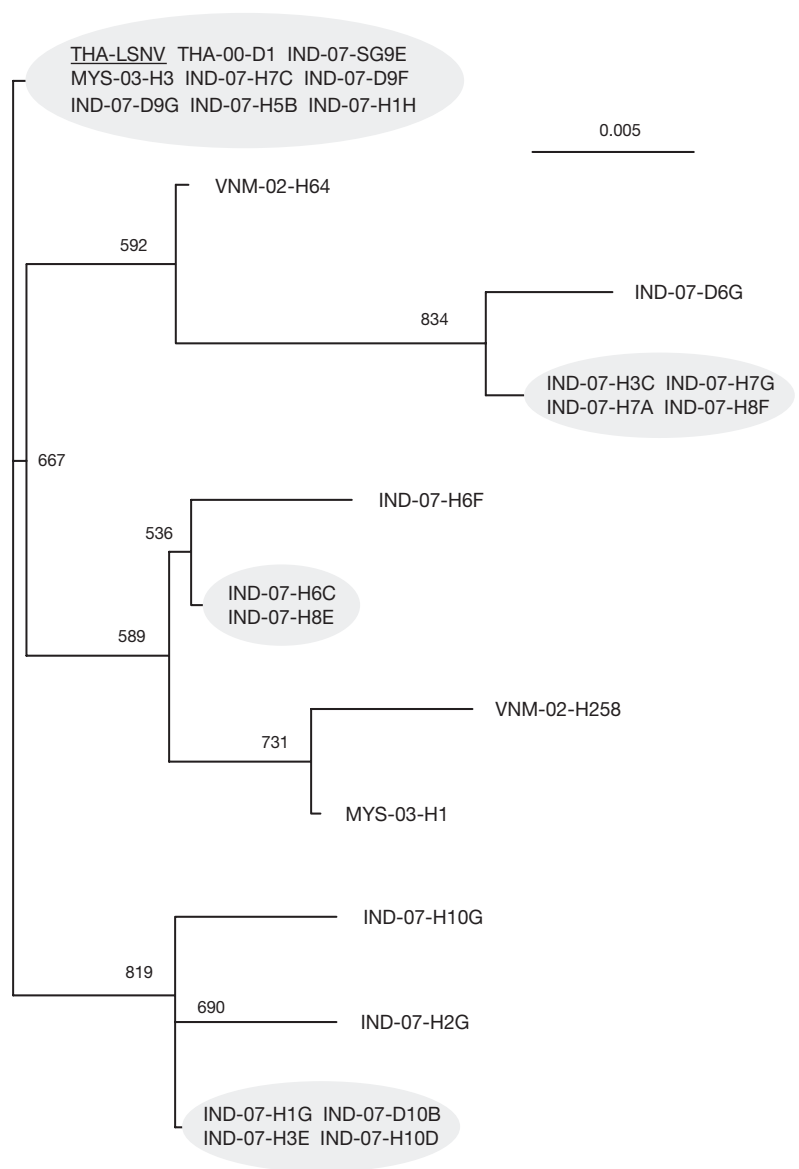

Fig. 1. Neighbour-joining phylogenetic tree constructed from a ClustalX multiple alignment of a 199 nucleotide sequence in the RdRp gene amplified by RT-PCR from 26 Laem-Singh virus (LSNV) isolates detected in Penaeus monodon from India (IND), Vietnam (VNM), Malaysia (MYS) and Thailand (THA). The countries of origin, year of collection and condition of the shrimp (H: healthy; D: diseased; SG: slow growth) are embedded in the virus codes. The tree was generated using the PHYLIP output in ClustalX, presented graphically using NJ-plot and drawn using Treeview Version 1.6.6 (Page 1996). Bootstrap values shown at branch points indicate branching frequency in 1000 replicates. Clusters of viruses with identical sequences are shaded

P. vannamei sampled from Thailand have origins as specific pathogen-free stock imported from Hawaii. The possibility that the natural host range of LSNV commonly includes other species therefore cannot be excluded.

Prakasha et al. (2007) have recently reported detection of LSNV by RT-nested PCR in only 3 of 56 Penaeus monodon samples tested from Karnataka (west coast) and Andhra Pradesh (east coast), India. The LSNVpositive shrimp were amongst 4 samples from Karnataka that displayed signs of loose shell syndrome. In our survey, the prevalence of LSNV infection in Andhra Pradesh was high (56.8\%) and, as observed previously in Thailand (Sritunyalucksana et al. 2006), we observed no particular association between LSNV infection and disease in the shrimp. However, the disease conditions described by field staff were as defined by Padiyar (2009) - i.e. (1) an abnormal reduction in feed consumption and increase in the number of shrimp with abnormal swimming behaviour and/or appearance; (2) an increase in the number of dead or moribund shrimp; or (3) a farmer-initiated emergency harvest - and there were no specific observations with respect to loose shell syndrome. Although we did detect a very high prevalence of LSNV in P. monodon from MSGS ponds at 2 sites in Thailand, previous studies and the surveys from the present study indicate that LSNV infection also occurs commonly in healthy shrimp. Clearly, the prevalence of LSNV infection can vary significantly in different populations of $P$. monodon and, as stress is commonly a stimulus for the onset of disease, more work is required to elucidate possible associations with loose shell, slow growth or other pathologies.

Phylogenetic analysis suggested that the extent of variation in LSNV across India and Southeast Asia is relatively low, and there was no clustering of viruses according to the site of sampling. However, the amplicon sequence used in the present study was small (199 nt) and is located in a highly conserved region of the genome encoding the viral RNA-dependent RNA polymerase (Sritunyalucksana et al. 2006); it is possible that more variable regions would be more useful in delineating strains. Nevertheless, analysis of yellow head complex viruses using amplicons in similarly conserved regions of the viral replicase gene have indicated far more nucleotide sequence variation and the clustering of isolates into genotypes, some of which have geographic associations (Wijegoonawardane et al. 2008a,b). Virus purification and genome sequence analysis currently in progress will provide the tools for more informative analysis of the genetic structure of LSNV populations in shrimp.

Acknowledgements. The present study was conducted as a multilateral research cooperation supported by the Australian Centre for International Agricultural Research (ACIAR) and the Marine Products Export Development Authority (MPEDA), Government of India. We particularly thank the MPEDA Director, B. Vishnu Bhat, for his strong support and encouragement. The authors also thank P. K. M. Wijegoonawardane, K. V. Rajendran and J. A. Cowley of CSIRO Livestock Industries, Brisbane, Australia, M. Leartvibhas and A. Boon-nat of Charoen Pokphand Foods PLC, Thailand, and S. Waqairatu of University of the South Pacific, Fiji, for supplying shrimp tissues and/or extracted RNA. 


\section{LITERATURE CITED}

Anantasomboon G, Sriurairatana S, Flegel TW, Withyachumnarnkul B (2006) Unique lesions and viral-like particles found in growth retarded black tiger shrimp Penaeus monodon from East Africa. Aquaculture 253:197-203

Chayaburakul K, Nash G, Pratanpipat P, Sriurairatana S Withyachumnarnkul B (2004) Multiple pathogens found in growth-retarded black tiger shrimp Penaeus monodon cultivated in Thailand. Dis Aquat Org 60:89-96

Padiyar A (2009) Epidemiology and management of Penaeus monodon farms in Andhra Pradesh, India. PhD thesis, Deakin University, Victoria

Page RDM (1996) Tree View: an application to display phylogenetic trees on personal computers. Bioinformatics 12: 357-358

Prakasha BK, Ramakrishna RP, Karunasagar I, Karunasagar I (2007) Detection of Laem-Singh virus (LSNV) in cultured

Editorial responsibility: Alex Hyatt,

Geelong, Victoria, Australia
Penaeus monodon from India. Dis Aquat Org 77:83-86

Saitou N, Nei M (1987) The neighbor-joining method: a new method for reconstructing phylogenetic trees. Mol Biol Evol 4:406-425

Sritunyalucksana K, Apisawetakan S, Boon-nat A, Withyachumnarnkul B, Flegel TW (2006) A new RNA virus found in black tiger shrimp from Thailand. Virus Res 118:31-38

Walker PJ, Mohan CV (2009) Viral disease emergence in shrimp aquaculture: origins, impact and the effectiveness of health management strategies. Rev Aquac 1:1-30

Wijegoonawardane PKM, Cowley JA, Phan T, Hodgson RAJ, Nielsen L, Kiatpathomchai W, Walker PJ (2008a) Genetic diversity in the yellow head nidovirus complex. Virology 380:213-225

Wijegoonawardane PKM, Cowley JA, Walker PJ (2008b) Consensus RT-nested PCR detection of yellow head complex genotypes in penaeid shrimp. J Virol Methods 153: 168-175

Submitted: January 5, 2009; Accepted: March 16, 2009 Proofs received from author(s): April 16, 2009 